\title{
A SYSTEMIC ANALYSIS OF TWO TURKISH TRANSLATIONS OF HEMINGWAY'S THE OLD MAN AND THE SEA*
}

\author{
Harika KARAVIN**
}

\begin{abstract}
This study aims to provide a systematic and objective translation criticism, , benefiting mainly from Van den Broeck's "systemic model of translation criticism". Instead of searching for errors in translations, the textual and extra-textual features of the source and target texts have been tried to be defined and "the shifts of expressions" have been identified by linking each text to their social contexts. For the analysis and description of the translator's strategies on macro level, Venuti's concepts of domestication and foreignization have been used as analytical categories. For micro level analysis, on the other hand, Vinay and Darbalnet's translation procedures have been applied, providing relevant examples on different levels.
\end{abstract}

Keywords: translation criticism, systemic model, shifts of expressions, domestication and foreignization

\section{HEMINGWAY'IN İHTIYAR ADAM VE DENIZ ADLI ROMANININ İKİ TÜRKÇE ÇEVIRISIININ DİZGESEL ANALIZİ}

\section{ÖZ}

Bu çalışma temel olarak Van den Broeck'ün dizgesel çeviri eleştiri modelinden faydalanarak sistematik ve objektif bir çeviri eleştirisi sunmayı hedeflemektedir. Çevirilerde hata aramak yerine, kaynak ve erek metinlerin metinsel ve metin dışı özellikleri tanımlanmaya çalışılmış, metinlerdeki "deyiş kaydırmaları" metinlerin sosyal bağlamları göz önünde bulundurularak belirlenmiştir. Makro düzeyindeki çevirmen kararlarının incelenmesi ve tanımlanmasında analitik kategori olarak Venuti’nin yerelleştirme ve yabancılaştırma kavramları kullanılmıştır. Mikro düzey incelemelerde ise Vinay ve Darbalnet'in çeviri prosedürleri uygulanıp, farklı düzeylerde ilgili örnekler verilmiştir.

Anahtar sözcükler: çeviri eleştirisi, dizgesel model, deyiş kaydırmaları, yerelleştirme ve yabancılaştırma Introduction

Since the establishment of the Translation Bureau in 1940, Turkish literary system has been extensively enriched by translations from various languages and the translation activity has been evaluated by writers, translators and critics. However, most of the evaluative practices have appeared in some particular forms such as translator's prefaces, annotations and book reviews. These practices have usually focused on the translated texts without paying attention to their source texts. Therefore, the criticism of translation in Turkey has been rarely productive and had a tendency to judge the translated texts on the basis of their defects. Even more recently, the majority of the critics have described translations with some commonplace statements such as "it

*Makale Gönderim Tarihi: 29 01 2016; Makale Kabul Tarihi: 21.09.201

**Gelişim Üniversitesi Uygulamalı İngilizce çevirmenlik programı öğretim görevlisi, harika.karavin@gmail.com 


\section{BUJSS}

9/2 (2016), 130-142

reads well" or "it is bad" without supporting their remarks with objective and relevant criteria. These highly subjective appraisals have led some of the scholars to make a call for descriptive and systematic evaluations, which has consequently caused a paradigm change in Translation Studies. A number of prominent scholars including Itamar Even Zohar have had significant roles on this paradigm change with their emphasis that target text is at least as much important as the source text. In their "target oriented and systemic approach", the quality of translation is assessed according to the function of the translation in the system of the target literature. They have looked upon the literary translations as part of the polysystem of the target culture literature. In addition, Gideon Toury has put forward a methodology for descriptive translation studies and suggested that translators constantly take some decisions during their translation processes. He has attempted to examine them through the notion of "translational norms" (1978). In short, scholars working within this paradigm have claimed that translations should be described in accordance with the target norms that are valid at a specific time and place and compared with their original ones in order to produce an objective translation criticism supported by translation theories (Toury, 1980, p. 73).

In order to produce such kind of a systematic and objective translation criticism, I want to examine two Turkish translations of Hemigway's novella the Old Man and the Sea by adopting Van den Broeck's "systemic model of translation criticism and reviewing" (1985, p. 55). Before starting my analysis, I would like to give some information about the theoretical basis on which this model is grounded. According to Van den Broeck, translation criticism can be an objective account if it is based on systematic description, which requires, as a first step, a comparative analysis of the source and target texts. The purpose of this kind of comparison is to determine the degree of "factual equivalence" between the source and target texts. To put it differently, one of the most important aims of this model is to find out what kind of relationship exists between these two texts without offering value judgments. However, it is not enough to restrict this comparison only to the text structures. He requires the critics to take into account the "multiple relations between the source text and the system of similar and/or other texts originating from the same language, culture and tradition; between the target and source systems; between the target text and its readers and so on" (p. 59). As he claims, the comparison of ST and TT should also identify the shifts of expressions in the translation. Incorporating Popovic's notion of the "shifts of expressions" into his translation criticism model, he has managed to avoid defining every change in the target text as an "error". As Popovic defines, "all that appears as new with respect to the original, or fails to appear where it might have been expected, may be interpreted as a shift. According to him, the differences in languages are unavoidable due to the "disparity and asymmetry in the development of two linguistic traditions. Therefore, any changes in the target text should not be interpreted as something 


\section{BUJSS}

9/2 (2016), 130-142

negative that results from the translator's desire to change the "semantic appeal" of the source text. As he argues, the translator sometimes resorts to shifts in their translations in order to "preserve the norm of the original" (1970, pp. 79-81). For this reason, determining the nature of the shifts in the translated texts (optional vs. obligatory) would enable the critic to evaluate the translator's strategies as well as what is "lost" or "gained" in the translation process in a much more objective manner. Van den Broeck also adds that the critic should strive to "detect the translator's norms and options, the conditions under which he works and the way in which they influence the translational process". Above all, the critic should never confuse his own set of norms with those adopted by the translator (pp.59-61)

In the view of the information mentioned above, I will compare Hemingway's novella with its two specific Turkish translations. One of them was translated by Ülkü Tamer and published by Varlık Publishing House in 1969. The reason why I have chosen this version is my wide knowledge about the translator. Ülkü Tamer is a well-known poet, translator and actor who is famous for his simple and plain language style. He is one of the best representatives of the literary movement called İkinci Yeni. Tamer is usually defined as a poet who has admired the West and has been greatly influenced by its ideas (Mehmet Fuat, 1985). As a second option, I have chosen Orhan Azizoğlu's translation, published by Bilgi Publishing House in 1983, since it is the only one that still circulates in the market and is mostly read by the primary school students as one of the "100 Essential Works" recommended by the Ministry of Education.

\section{A Comparative Analysis of Source and Target Texts}

In this part of the study, I will provide a comparative analysis of the source and target texts, focusing on both linguistic and extra-linguistic elements. My analysis will provide much space to examine how translators reflect Hemingway's lexical choices and stylistic elements. While defining the translators' strategies, I will benefit from Venuti's concepts of domestication and foreignization as analytical categories to describe two opposite ways of translating on the macro level. As is known, "domestication is used to refer to the adaptation of the culture context and culture specific items and foreignization to the preserving of the original cultural context" (Paloposki, 2011, p. 1). The reason why Venuti introduces these concepts is his desire to formulate an ethical agenda. He dismisses the domestication strategy since it involves "an ethnocentric reduction of the foreign text to target language cultural values" (1995, p. 20). This results in a transparent and fluent translation, which increases the invisibility of the translator by minimizing the foreignness of the source text. On the contrary, he is in favor of the foreignizing method that entails "choosing a foreign text and developing a translation method along lines which are excluded by dominant culture values in the target language". In this way, Venuti aims to put an ethnodeviant pressure on target-culture values to register the linguistic and cultural 


\section{BUJSS}

9/2 (2016), 130-142

differences of the foreign text and make visible the presence of the translator (ibid.). For micro-level linguistic and stylistic analysis, I will use Vinay and Darbalnet's model which provides different translation strategies and procedures. Vinay and Darbalnet identify seven procedures, each of which is adopted in particular circumstances. For instance, borrowing refers to the usage of foreign words in target text in order to "introduce the flavor of the source language culture into a translation". Calque is defined "as a special kind of borrowing" where source language structure or lexical element is transferred literally into target text. Literal translation is the direct transfer of SL text into an "idiomatically and grammatically appropriate" target text. Transposition refers to the change of word class with another; modulation to the changes in point of view of the source text; equivalence to the description of same situation by different stylistic and structural means; adaptation to changing the cultural references in target text when the situation of source text is unknown in the target culture (1958, pp. 85-93).

\subsection{Lexical Elements}

\subsubsection{Translation of ideologically-laden words}

As we know, every language use involves some kind of ideology, which can manifest itself through the selection of some specific lexical or grammatical items. Therefore, it is possible to determine an author's ideological stance by studying the lexical units in the text. In order to evaluate the ideological aspect of the language use in this novella, it is important to know that Hemingway intentionally adds some Spanish words into his text to show his interest and familiarity with the people of Cuba where he lived for more than fourteen years. He uses lots of ideologically-laden words such as bodega, salao, el mar, terrace, queva etc. Even the name of the main character, Santiago, is a Spanish word that is commonly used to denote the Saint James. Now, I would like to give two examples to analyze how the translators deal with such words:

"But after forty days without a fish the boy's parents had told him that the old man was now definitely and finally salao, which is the worst form of unlucky [...]" (p.9)

Tamer: "Ama balıksız geçen kırk gün sonunda, çocuğun ailesi, ihtiyar adamın artık düpedüz salao olduğunu, kör talihli olduğunu, söylemişti.” (p.7)

Azizoğlu: "Fakat birbiri ardından kırk gün eli boş döndükten sonra çocuğun ailesi, ihtiyar balıkçının artık talihsizlikten de beter bir salao'ya uğradığına inanmıştı." (p.5)

Both of the translators adopt the borrowing method by preserving the foreign word in their translations so that they could reflect the ideology behind the author's decision to choose this Spanish word. Hemingway intentionally uses this word in the source text to imply the nationality of the boy in the novella and show his own familiarity with this language and the people of Spanish origin living in Cuba. Tamer both keeps the 


\section{BUJSS}

9/2 (2016), 130-142

foreign word and explains it with a parenthetical statement in the TT. His expression "kör talihli" manages to render the high degree of unluckiness the old man experiences. On the other hand, Azizoğlu highlights its foreignness by writing it in bold. However, we observe a "negative shift" in his version. Though the word salao is defined as the worst form of unluckiness in the ST, he presents is as something different that is possible to be compared to the state of being unlucky in terms of its emotional intensity. Since he does not provide any explanation regarding the lexical meaning of this word, either within the same sentence or by using a footnote, it might be difficult for the readers to interpret it as "being very unlucky". The following example also deals with the translators' strategies to cope with a similar Spanish word:

"Some of the younger fishermen, those who used buoys as floats for their lines and had motorboats, bought when the shark livers had brought much money, spoke of her as el mar which is masculine.” (p.30)

Tamer: "Genç balıkçılardan bazıları, ağları için mantar yerine şamandıra kullananlar, köpek balığı ciğerinin para ettiği zamanlar alınmış motorlarla balıkçılık edenler, erkeklik belirtisi olan el'i kullanırlardı: el mar." (p.27)

Azizoğlu: "Ağlarının başına şamandıra koyan, köpekbalığı ciğeri fazla para ettiği zaman motorlu kayık alan genç balıkçılardan bazıları, ondan, erkek olarak El Mar diye söz eder.” (p.27)

Here, the author uses another Spanish word, el mar, which means the sea. Mar is an unusual noun in that it can be used either with masculine or feminine definite article. As is told in the story, the majority of the Spanish people describes the sea as feminine and hence uses the feminine definite article "la". However, some of the younger fishermen prefer to speak of it as masculine and therefore the masculine definite article "el" precedes the word. When we look at the translations of the word "el mar," we see that the translators again adopt the borrowing strategy, which helps them to reflect Hemingway's ideological lexical choices in the translated versions. In both translations, it is easy to understand that people use "el mar" when they want to talk about the sea as masculine. However, it not so easy to determine whether it is really so or something made up by those people. Therefore, it would be useful to use a footnote that would both provide information about what "elmar" means and the function of the article "el". In this way, it would be possible to solve the ambiguity that is apparent in Tamer's explanatory phrase preceding this article. When "el" is defined as "erkeklik belirtisi", the person reading Tamer's translation may interpret it as a kind of feature belonging to men.

\subsubsection{Translation of fishing terms}

One of the unique characteristics of the novella results from Hemingway's extensive use of fishing terms and details regarding fishing techniques. In other words, this novella can be considered a reflection of Hemingway's expert knowledge and skill in fishing. As Gurko points out, “one reason that Hemingway's 


\section{BUJSS}

9/2 (2016), 130-142

stories are so crammed with technical details about fishing, hunting, bullfighting, boxing, and war is his belief that professional technique is the quickest and surest way of understanding the physical process of nature, of getting into the thing itself." (1955, p. 15). For this reason, translators need to have enough knowledge on some basic fishing terminology and strategies. In addition, Hemingway includes various kinds of fish into his plot such as albacore, bonita, marlin and tuna, all of which have symbolic functions. Throughout the novella, a connection is usually formed between the old man and the fish in order to show his lack of control both on himself and the nature. Now, I would like to analyze what kinds of strategies the translators have adopted to render the parts that are closely related to fishing.

"[...] he had a big blue runner and a yellow jack that had been used before"(p.31)

Tamer: “Ötekilerde daha önce kullandığı kocaman mavi bir lüferle, sapsarı bir lapina takılydı”. (p.29)

Azizoğlu: “Ötekilere bir gün evvel kullandığı yemleri takmıştı.” (p.28)

This sentence is taken from a scene where the narrator describes the fishing lines the old man and the little boy cast into the sea. The phrases "big blue runner" and "yellow jack" refer to the specific fishing terms that denote the replicas used as bait in order to attract the fish. Azizoğlu manages to understand this point and prefers to use a culturally-neutral word "yem". On the other hand, Tamer also understands their function, but attempts to render all the lexical elements in his translation by adapting the names of the fish. Instead of preserving the "big blue runner" and "yellow jack", which are distributed mainly across the Atlantic Ocean, he uses the names of other two fishes that are known to the Turkish culture. In his method of adaptation, he seems to pay attention to the fact that the fish types that he would use could be qualified with the adjectives "yellow" and "blue". However, his version ends up creating a "negative shift", resulting from the adjective "kocaman" that precedes the replicas which are, in fact, quite small in size.

In the following example, I will focus on the different lexical choices used for rendering some specific fishing terms:

He shipped his oars and brought a small line from under the bow. It had a wire leader and a medium-sized hook and he baited it with one of the sardines. He let it go over the side and then made it fast to a ring bolt in the stern. Then he baited another line and left it coiled in the shade of the bow." (p.34)

Tamer: "Kürekleri bırakıp küçük bir olta çıkardı başaltından. Orta boy iğnesine sardalyelerden birini taktı. Yandan suya bıraktı oltayı, kıçtaki halkalardan birine bağladı. Sonra bir başka oltaya daha yem takarak başaltında gölgeye koydu onu.” (p.31)

Azizoğlu: "Kürekleri bırakarak başaltından daha ince bir olta çıkardı. Tel bir kılavuzun ucundaki orta boy zokayı, sardalyelerden biriyle yemledikten sonra denize firlatıp bodoslamadaki halkalardan birine sıkıca 


\section{BUJSS}

9/2 (2016), 130-142

bağladı. Sonra bir başka olta daha hazırlayıp, pruvanın gölgesine bıraktı.” (p.31)

The fishing terms "bow," "stern" and "hook" are translated with different words by the translators. As is seen, Azizoğlu has a tendency to use more technical words than those of Tamer's. For instance, while Tamer renders "stern" as "kıç", Azizoğlu uses "bodoslama". Tamer seems to take the audience factor more into account, which is assumed to be mainly the primary-school children, with his preference for a more familiar word. When we look at the translation of "bow", it is easily recognized that the translators become confused with the semantic nuance between "pruva" and "başaltı". While "pruva" can be used to refer to the forward end of a small boat, "başaltı" denotes deck heads of the seamen in ships. In fact, the old man goes on fishing on a small boat and hence the choice of "başaltı" for "bow" creates a negative shift in both translations.

\subsubsection{Translation of culture-specific items}

As the distance between cultures and languages increases, rendering of culture-specific items becomes more problematic. Deficient familiarity with the cultural background of the source text usually causes "negative shifts" in translations. In order to deal with such words, translators develop strategies that can be identified, in general terms, by using Venuti's concepts of domestication and foreignization. My analysis will include the rendering of the following two categories: (1) baseball terms, (2) biblical names.

The reason why I have chosen to analyze the baseball terms results from the intensity of the dialogues between Santiago and Marlin about American baseball and one of its players, Joe DiMaggio. At the beginning of the novella, an analogy is formed between Santiago and Joe DiMaggio, who is identified as a hero. Both men continue to put up a struggle no matter how worse the conditions are. As baseball is an unknown type of sport for Turkish readers, it would be interesting to analyze how the translators have rendered such parts. Let's start with the translation of the word "baseball":

"Go and play baseball" (p.12) / "When I come back you can tell me about the baseball" (p.17) / "[...] and I will read the baseball." (p.17)

Tamer: "Git ve beyzbol oyna" (p.10) / "Dönünce beyzbolu anlatırsın" / "Beyzbol haberlerini okurum" (p.14)

Azizoğlu: "Sen git topunu oyna." (p.8) / Ben dönene kadar maçları oku da bana anlatırsın." (p.13) / "Maçları okurum" (p.13)

As is seen, Tamer adopts the borrowing method and transfers the foreign word into the target text. Tamer seems to be aware of the associations this term arouses in the representation of the content in that he adopts a foreignizing strategy whenever such terms appear in the novella. However, Azizoğlu displays an opposite tendency, adopting the method of adaptation in rendering the word "baseball". In each instance, he adapts the 


\section{BUJSS}

9/2 (2016), 130-142

typically American sport "baseball" into a familiar sport "football" and renders the relevant terms accordingly. For instance, while translating the word "baseball" in the last sentence, Azizoğlu completely ignores its cultural attributes and present it with a culturally-neutral word "maç". The reason behind Azizoğlu's strategy might be his desire to enable the target readers to see and understand it within their own cultural context, without confusing their minds with something unknown to them.

Now, I would like to analyze a dialogue in which Santiago and Manolin has a conversation about some of the baseball teams:

"The Yankees cannot lose."

"But I fear the Indians of Cleveland."

"Have faith in the Yankees my son. Think of the great DiMaggio."

"I fear both the Tigers of Detroit and the Indians of Cleveland."

"Be careful or you will fear even the Reds of Cincinnati and the White Sax of Chicago." (p.17) Tamer:'s translation:

"Yankee yenilmez."

"Ama Indias of Cleveland'dan korkarım ben."

"Yankee’ye güven, oğlum. Büyük DiMaggio'yu düşünsene."

"Ben hem Tigers of Detroit'ten, hem de Indians of Cleveland'dan korkarım."

‘Neredeyse Reds of Cincinnatti’yle White Sox of Chicago'dan da korkacaksın. (p.15)

Azizoğlu's translation:

“Bizim Yankee'ler nasıl olsa kazanmıştır."

“Clevand'lı İndian'lar beni korkutuyor doğrusunu istersen."

“Sen niyetini bozma evlat. Bizim Yankee’ler iyidir. Di Maggio’yu düşünsene, aslan gibi oyucu.”

"Detroit'li Tiger'lar da belalı."

“Ha gayret, nerdeyse Cincinattiler'den, Chiacogo'lulardan da korkacaksın. Bu ne be!” (p.14)

Hemingway intentionally includes some team names into his plot because he wants to emphasize that the struggles of the game resemble those of the old man's. The excerpt given above can be examined within this framework, paying attention to the translators' translation strategies that differ from each other. On the one hand, Tamer transfers all the foreign names by using the borrowing method without changing their spelling. Though his choice can be justified by referring to his desire to keep proper names as they are, it is not obvious whether the names belong to a team or a player because within the same dialogue we also encounter the name of a famous player, Di Maggio. Therefore, Tamer might have avoided the confusion by adding the word 


\section{BUJSS}

9/2 (2016), 130-142

"team" after the names. What is more, Tamer fails to recognize the play on the words. In fact, the teams are called 'the Cleveland Indians', 'the Cincinnati Reds', 'the Chicago White Sox', and 'the Detroit Tigers'. On the other hand, Azizoğlu translates the names literally into Turkish (e.g. Detroit'li Tiger'lar, Clevand'lı Indian'lar), which causes ambiguity in the target text. In his translation, it is possible to deduce that the names of the teams are Tiger and İndian and their preceding words are used just to explain their home towns. Ambiguity becomes more intense in the last sentence where Azizoğlu only transfers the city names. In order to avoid such problems, it would be better if the translators provided footnotes that specify what these names refer to.

\subsection{Stylistic elements}

\subsubsection{Hemingway's use of details}

Even though Hemingway uses short sentences that are written in simple and natural language, he forces the readers to focus on the components of each sentence and examine the details more closely. As a minimalist writer, Hemingway's strength lies in his short sentences that include specific details in themselves (Xie, 2008, p. 156). The following examples will attempt to show whether translators have paid attention to preserve the details of the source text in their translations:

"The successful fishermen of that day were already in and had butchered their marlin out and carried them laid full length across two planks, with two men staggering at the end of each plank, to the fish house where they waited for the ice truck to carry them to the market in Havana." (p.11)

Tamer: "O günün başarılı balıkçıları dönmüşlerdi bile, yakaladıkları marlin’i karaya çekip iki kalasın üstüne boylu boyunca uzatmışlardı; birer adam kalasların ucuna yapışmış, Havana' daki pazara gidecek buz kamyonunu beklemek için balıkhaneye götürüyorlardı balığı.” (p.9)

Azizoğlu: "O günün şanslı balıkçıları dönmeye başlamışlardı bile. Uzun kalaslar üzerine yatırdıkları kılıç balıklarını Havana pazarına sevk edilmek üzere buzhaneye götürüyorlardı.” (p.7)

In this example, the narrator gives a detailed description of what is done after catching the marlin. Then, within the same paragraph, the narrator continues his/ her narration by adding another piece of detailed information regarding the handling process of sharks. As the differences in dealing with different types of fish are aimed to be shown, each details gains importance in this paragraph, all of which are tried to be kept in Tamer's translation. He includes all the components of the source text into his translation and hence carries out a "faithful translation" in the sense of preserving all of the lexical elements within the constraints of the grammatical and lexical structures of the target language. In Azizoğlu's translation, however, we see that he omits the specific parts written in bold from the sentence. The details regarding who carries the marlin and by 


\section{BUJSS}

9/2 (2016), 130-142

which they are transported to the market are not mentioned in the TT. In the general sense, his translation strategy can be defined as a freer rendering of the source language text, having less concern to render each individual word. Due to such kind of reduction and simplification in the target text, Azizoğlu fails to reflect one of the stylistic elements of Hemingway in his translation.

\subsubsection{Hemingway's simple language}

Hemingway's idiosyncratic language use results mostly from its simplicity, directness, clarity and freshness. He almost always uses concrete, specific, more common, casual and conversational words in his works. He prefers to use short sentences that rarely include adjectives and abstract nouns (2008: 157). However, he creates a particular tension and rhythm in these sentences, which becomes more of an issue in the translations. Now I would like to analyze how the translators reflect Hemingway's direct and simple language in their translations.

"The old man had thought the boy to fish and the boy loved him." (p.10)

Tamer: "Balık tutmayı ihtiyar adam öğretmişti ona; çoçuk onu seviyordu.” (p.8)

Azizoğlu: "Çocuğun delicesine sevdiği balıkçılığı ona ihtiyar öğretmişti.” (p.6)

The sentence in the source text is a perfect indicator of Hemingway's style. As is seen, the message is clear and direct. In Tamer's translation, we observe that he adopts a source oriented approach in terms of representing the particular stylistic features of the source text. In other words, Tamer seems to take into account the stylistic components of source text with regard to simple and direct language. Unlike Azizoğlu, he does not add or delete anything in his translation. When we look at Azizoğlu's translation, we begin to feel that this sentence has been uttered by someone else rather than Hemingway, which manifest itself on different levels. First of all, Azizoğlu translates the author's expression in one sentence while the statement in the source text consists of two clauses that are linked to each other in a sequential way. Secondly, the author's direct expression is turned into an indirect one, causing a shift in emphasis. In his translation, the emphasis is put on the fact that "the old man taught him to fish". However, in Hemingway's sentence, that the old man taught him and he loved him is of equal importance. In addition, Azizoğlu's expression "çoçuğun delice sevdiği balıkçılığı" causes a "negative shift", resulting from a misinterpretation. It is not the fishing that the little boy loved, but the old man himself.

\subsubsection{Hemingway's use of repetition}

Hemingway employs the technique of repetition to "convey action clearly to the reader and to create the impression that it is happening in the present" (2008: 157). That is to say, Hemignway usually resorts to repetition within the same sentence or paragraph in order to achieve a particular effect. This point gains 


\section{BUJSS}

9/2 (2016), 130-142

significance when one is to judge the translation of a literary work. For this reason, I would like to examine whether the translators take into account this stylistic feature in their translations.

"And maybe he will come up before that. If he doesn't maybe he will come up with the moon. If he does not do that maybe he will come up with the sunrise." (p.46)

Tamer: "Belki o zamana kadar su yüzüne çıkar. Çıkmazsa belki ay doğunca çıkar. Ay ışığında da çıkmazsa güneş doğarken çıkar belki.” (p.43)

Azizoğlu: "O zamana kadar yüze çıkıverir bakarsın, belli olmaz. Olmazsa gece ay çıkınca gelir belki. Ya da güneş doğarken yola getiririz.” (p.44)

Here the narrator talks about the probability of encountering the marling by a certain time. Repeating the words "maybe" and "come up" three times within three successive sentences, Hemingway creates a kind of tension and rhythm in narration. Tamer shows a tendency to produce a target text that follows closely the "textual-linguistic norms" of the source text and culture. His translation manages to recreate the same impression in the target text by employing the author's technique of repetition. As is clear, the words "maybe" and "come up" are rendered by "belki" and "çıkar" respectively, without using any other expressions. However, Azizoğlu prefers to use different words for them in each sentence (e.g. "çıkıverir", gelir" for the translation of "come up"). He does not even include one of the repeated elements in his translation (translation of "maybe" is omitted in the last sentence). As a result, he fails to recreate the intended rhythm in his version. In addition, he includes his own subjective interpretation by changing the content of the source text. Though the narrator speculates about the time when the marlin comes into sight within the whole excerpt, Azizoğlu introduces a different semantic context into the last sentence with his expression "yola getirmek".

\section{Conclusion}

In this study, I have attempted to provide a systematic and objective translation criticism, benefiting mainly from Van den Broeck's "systemic model of translation criticism". Instead of searching for errors in translations, I have tried to describe the textual and extra-textual features of the source and target texts and identify "the shifts of expressions" by linking each text to their social contexts. In order to define the translator's strategies on macro level, I have used Venuti's concepts of domestication and foreignization as analytical categories. For micro level analysis, on the other hand, I have made use of Vinay and Darbalnet's translation procedures whenever it is necessary and relevant. Even though I have encountered a huge number of examples that can be discussed within the framework of a negative shift, I have tried to restrict my analysis to Hemingway's lexical and stylistic features and their representation in the translations.

At the end of the study, I have gained significant information regarding the translators' 


\section{BUJSS}

9/2 (2016), 130-142

translation strategies. In translating ideological words used by Hemingway, both of the translators have failed to convey the intended message because the target readers have not been provided with any relevant footnotes that would help them to understand them more appropriately. Though the translators have had a tendency to maintain the foreignness of the source text, they have not been always able to compensate for the cultural differences or make the text more intelligible for the target readers. Apart from that, Tamer has tried to produce a more "faithful" translation in terms of representing Hemingway's lexical and stylistic elements by using a simple Turkish as well as direct and short sentences. Considering this, we can say that Tamer was under the influence of the dominant translation discourse of his time which appreciated to reproduce the style and content of the author as faithfully as possible. Finally, it is possible to mention that more negative shifts have been encountered in Azizoğlu's translation, most of which have resulted from misinterpretation, lack of knowledge about fishing and lack of attention. Therefore, we can conclude that Azizoğlu has sometimes been less successful in reading the source text correctly.

\section{REFERENCES}

Azizoğlu, Orhan, (trans. 1983). İhtiyar Balıkçı. by Ernest Hemingway. Ankara: Bilgi Yayınevi.

Baker, Carlos. (1969). Ernest Hemingway: A Life Story. New York. Charles Scribner's Sons.

Durisin, D. (1974). Sources and Systematics of Comparative Literature. Bratislava: Univerzita Komenskeho.

Even-Zohar, Itamar. (1978). "The Position of Translated Literature within the Literary Polysystem”. J.S.holmes, J.Lambert, R.Van den Broek der. Literature and Translation: New Perspectives in Literary Studies. Leuven: ACCO.

Elizondo, Sonny. (2011). GradeSaver(TM) Classic Notes: The Old Man and the Sea.

Available:<http://www.amazon.com/exec/obidos/ASIN/160259273X/gradesaver-20> (assessed 3 June 2013).

Fuat, Mehmet. (1985). Çağdaş Türk Şiiri Antolojisi. İstanbul: Adam Yayınları.

Gurko, Leo. (1955). "The Old Man and the Sea", College English Vol. 17, No: 13, Oct 1955.

Hemingway, Ernest. (1952). The Old Man and the Sea. New York: Scribner.

House, Juliane. (2001). “Translation Quality Assessment: Linguistic Description versus Social Evaluation”. Meta, Vol. 46, No: 2.

Nelson, R. S. (1979). Hemingway: Expressionist artist. Ames, Iowa: The Iowa State University Press.

Paloposki, O. (2011). "Domestication and Foreignization” in Handbook of Translation Studies.

Pearsall, Robert Brainard. (1973). The Life and Writings of Ernest Hemingway. Amsterdam: Rodopi NV. 
BUJSS

9/2 (2016), 130-142

Popovic, Anton. (1970). “The Concept of 'Shift of Expression' in Translation Analysis”, The

Nature of Translation: Essays on the Theory and Practice of Literary Translation, (ed.) James S.

Holmes. The Hague and Paris: Mouton.

Schaffner, Christina. (2003). "Third Ways and New Centres” in Maria Calzada Perez, Apropos of Ideology, St. Jerome.

Tahir Gürçağlar, Şehnaz. (2009). Translation, Presumed Innocent: Translation and Ideology in Turkey. The Translator, Vol. 15, No: 1, 2009: Special Issue. Nation and Translation in the Middle East.

Tamer, Ülkü, trans. (1969). İhtiyar Balıkçı. by Ernest Hemingway. Ankara: Varlık Yayınları.

Toury, G. (1978). "The Nature and Role of Norms in Literary Translation” in L. Venuti.

(1980). In Search of a Theory of Translation, Tel Aviv: The Porter Institute.

Ulrych, Margherita. (1996). "On Integrating Stylistics into the Translation Process”. XIV World

Congress of the FIT. Proceedings 2. Melbourne, Australia: AUSIT, The Australian Institute of Interpreters and Translators.

Xie, Y. (2008). Hemingway's Language Style and Writing Techniques in The Old Man and theSea. CCSE Journal, Vol. 1, No:2, December 2008.

Van den Broeck, Raymond. (1985). "Second Thoughts on Translation Criticism: A Model of its Analytic Function" in T. Hermans (ed.), The Manipulation of Literature, Studies in Literary Translation. London/ Sydney: Croom Helm.

Venuti, L. (1995). The Translator's Invisibility: A History of Translation. London and New York: Routledge.

Vinay and Darbalnet. (1995). Comparative Stylistics of French and English: A Methodology for Translation. Amsterdam and Philadelphia, PA: John Benjamins. 